\title{
Stable carbon isotope fractionation during methanogenesis in three boreal peatland ecosystems
}

\author{
P. E. Galand ${ }^{1,2}$, K. Yrjälä ${ }^{3}$, and R. Conrad ${ }^{4}$ \\ ${ }^{1}$ UPMC Univ Paris 06, Observatoire Océanologique, 66651 Banyuls-sur-Mer, France \\ ${ }^{2}$ CNRS, FRE 3350, Laboratoire d'écogéochimie des environnements benthiques (LECOB), Observatoire Océanologique, \\ 66650 Banyuls-sur-Mer, France \\ ${ }^{3}$ Dept. of Biological and Environmental Sciences, General Microbiology, University of Helsinki, 00014 Helsinki, Finland \\ ${ }^{4}$ Max-Planck-Institute for Terrestrial Microbiology, Karl-von-Frisch-Str.10, 35043 Marburg, Germany
}

Received: 24 June 2010 - Published in Biogeosciences Discuss.: 16 July 2010

Revised: 2 November 2010 - Accepted: 10 November 2010 - Published: 29 November 2010

\begin{abstract}
The degradation of organic matter to $\mathrm{CH}_{4}$ and $\mathrm{CO}_{2}$ was investigated in three different boreal peatland systems in Finland, a mesotrophic fen (MES), an oligotrophic fen (OLI), and an ombrotrophic peat (OMB). MES had similar production rates of $\mathrm{CO}_{2}$ and $\mathrm{CH}_{4}$, but the two nutrientpoor peatlands (OLI and OMB) produced in general more $\mathrm{CO}_{2}$ than $\mathrm{CH}_{4} . \delta^{13} \mathrm{C}$ analysis of $\mathrm{CH}_{4}$ and $\mathrm{CO}_{2}$ in the presence and absence methyl fluoride $\left(\mathrm{CH}_{3} \mathrm{~F}\right)$, an inhibitor of acetoclastic methanogenesis, showed that $\mathrm{CH}_{4}$ was predominantly produced by hydrogenotrophic methanogenesis and that acetoclastic methanogenesis only played an important role in MES. These results, together with our observations concerning the collective inhibition of $\mathrm{CH}_{4}$ and $\mathrm{CO}_{2}$ production rates by $\mathrm{CH}_{3} \mathrm{~F}$, indicate that organic matter was degraded through different paths in the mesotrophic and the nutrient-poor peatlands. In the mesotrophic fen, the major process is canonical fermentation followed by acetoclastic and hydrogenotrophic methanogenesis, while in the nutrient-poor peat, organic matter was apparently degraded to a large extent by a different path which finally involved hydrogenotrophic methanogenesis. Our data suggest that degradation of organic substances in the oligotrophic environments was incomplete and involved the use of organic compounds as oxidants.
\end{abstract}

Correspondence to: R. Conrad (conrad@mpi-marburg.mpg.de)

\section{Introduction}

Northern peatlands cover about 400 million $\mathrm{km}^{2}$ (Gorham, 1991) and are important emitters of the greenhouse gas methane (Matthews and Fung, 1987; Bartlett and Harriss, 1993). Our knowledge about the methanogenic substrates and the pathway by which $\mathrm{CH}_{4}$ is produced is, however, still limited. Anaerobic degradation of organic matter eventually results in the production of acetate, $\mathrm{CO}_{2}$ and $\mathrm{H}_{2}$ as end products of fermentation (Zinder, 1993). Degradation of cellulose, for example, would result in the production of 2 acetate, $2 \mathrm{CO}_{2}$ and $4 \mathrm{H}_{2}$ from each hexose molecule, which are then further converted by acetoclastic and hydrogenotrophic methanogenesis to $3 \mathrm{CH}_{4}$ and $3 \mathrm{CO}_{2}$ (Conrad, 1999). Under these conditions, $2 \mathrm{CH}_{4}$ are derived from acetate and 1 $\mathrm{CH}_{4}$ from $\mathrm{H}_{2} / \mathrm{CO}_{2}$. In fact, this path of $\mathrm{CH}_{4}$ production has been demonstrated in various peat bogs ranging from Michigan (Avery et al., 1999), western Siberia (Kotsyurbenko et al., 2004) to the permafrost region of northwestern Siberia (Metje and Frenzel, 2007). In some peat ecosystems, however, acetoclastic methanogenesis is apparently impeded and $\mathrm{CH}_{4}$ is mainly produced from $\mathrm{H}_{2} / \mathrm{CO}_{2}$ (Lansdown et al., 1992; Horn et al., 2003; Metje and Frenzel, 2005; Prater et al., 2007). In Alaskan peatland acetate was found to accumulate instead of being further converted to $\mathrm{CH}_{4}$ (Duddleston et al., 2002). In a Finnish peat bog part of the acetate was found to be further converted to butyrate (Metje and Frenzel, 2005). Later studies indicated that a decreasing $\mathrm{pH}$ resulted in decreasing acetate turnover and in the relative dominance of hydrogenotrophic methanogenesis (Kotsyurbenko et al., 2007), and that the type of vegetation, i.e., dominance of Sphagnum

Published by Copernicus Publications on behalf of the European Geosciences Union. 
over vascular plants, coincides with the occurrence of acetate accumulation (Hines et al., 2008). When acetoclastic methanogenesis operates, it seems to occur preferably in the upper peat layers, whereas the deep layers are dominated by $\mathrm{CH}_{4}$ production from $\mathrm{H}_{2} / \mathrm{CO}_{2}$ (Popp et al., 1999; Chasar et al., 2000; Kotsyurbenko et al., 2004). These observations indicate that the quality of the degradable organic substances may affect the path of $\mathrm{CH}_{4}$ production (Chanton et al., 2008).

The methanogenic path is crucial for the extent of carbon isotope fractionation, as methanogenesis by $\mathrm{CO}_{2}$ reduction exhibits a much stronger fractionation factor than acetoclastic methanogenesis (Whiticar et al., 1986). Vice versa it is principally possible to use values of $\delta^{13} \mathrm{C}$ measured in $\mathrm{CH}_{4}$, $\mathrm{CO}_{2}$ and acetate to compute the relative contribution of each pathway to total $\mathrm{CH}_{4}$ production (Conrad, 2005). This approach has also been used for peat ecosystems (Lansdown et al., 1992; Avery et al., 1999; Hornibrook et al., 2000; Nakagawa et al., 2002; Prater et al., 2007; Steinmann et al., 2008; Knorr et al., 2008). Many systems have been studied without having information on the methanogenic microbial community. The operation of the acetate-dependent path requires the presence of acetoclastic methanogenic archaea which only occur in the genera Methanosarcina or Methanosaeta (Zinder, 1993), which are not always present in peat ecosystems (Horn et al., 2003; Kotsyurbenko et al., 2007; RooneyVarga et al., 2007). Hydrogenotrophic methanogenesis, on the other hand, occurs in almost every methanogenic taxon (Zinder, 1993), which are always present at more or less diversity in peat bogs.

Recently, we have studied three different peat ecosystems (a mesotrophic fen, an oligotrophic fen, and an oligotrophic ombrotrophic bog) in Finland, which differed in composition of the methanogenic archaeal community and also exhibited hydrogenotrophic and acetoclastic methanogenesis to different extent (Galand et al., 2005). While measuring $\mathrm{CH}_{4}$ production at different concentrations of methyl fluoride $\left(\mathrm{CH}_{3} \mathrm{~F}\right)$, an inhibitor of acetoclastic methanogenesis, we also determined the $\delta^{13} \mathrm{C}$ of $\mathrm{CH}_{4}, \mathrm{CO}_{2}$ and acetate. We report these data and quantify the relative contribution of hydrogenotrophic and acetoclastic methanogenesis to $\mathrm{CH}_{4}$ production. We hypothesized that the different peat ecosystems differ in the extent of isotope fractionation due to different paths of $\mathrm{CH}_{4}$ production with the nutrient poor ombrotrophic and oligotrophic systems exhibiting larger isotope fractionation than the mesotrophic fen.

\section{Methods}

Samples - Three replicate peat profiles were taken with a box sampler $(8 \times 8 \times 100 \mathrm{~cm})$ in August 2003 from the Lakkasuo mire complex in central Finland $\left(61^{\circ} 48^{\prime} \mathrm{N}, 24^{\circ} 19^{\prime} \mathrm{E}\right)$. The samples were taken from a mesotrophic fen (MES), an oligotrophic fen (OLI) and an ombrotrophic bog (OMB) at a depth of $10-20 \mathrm{~cm}$ below the water level. These layers ex- hibited the highest potential $\mathrm{CH}_{4}$ production rates (Galand et al., 2002). The hydrological conditions and vegetation cover of the sites have already been described in detail (Juottonen et al., 2005). Briefly, MES is a mesotrophic fen, the vegetation of which is a mosaic of lawn and minerotrophic hollow level communities with high diversity. The field layer in both communities is characterized by sedges (Carex rostrata, C. lasiocarpa) and some herbaceous species, such as Potentilla palustris and Menyanthes trifoliata. In the drier lawn surfaces, the bottom layer is dominated by Sphagnum mosses (S. fallax, S. flexuosum, S. magellanicum), whereas in wetter hollow surfaces Sphagnum subsecundum is found together with Warnstorfia exannulata and Utricularia intermendia. Study site OLI is an oligotrophic fen, which consists of a fairly homogenous lawn level vegetation, dominated by C. lasiocarpa with some Betula nana in the field layer, and Sphagnum papillosum, S. fallax and S. flexuosum in the moss layer. Water table in both fen sites MES and OLI is near the surface and has small spatial and seasonal variation. Site OMB is an ombrotrophic bog. It is a mosaic of ecohydrological gradients shown as changing plant communities from wet hollows to intermediate lawns and finally to drier hummock communities. In addition to spatial variation, water level has large seasonal variations. Eriophorum vaginatum, together with Andromeda polifolia and Rubus chamaemorus, is the most abundant field layer species; Sphagnum cuspidatum dominates in the bottom layer of the hollows, S. balticum in the lawns and S. fuscum in the hummocks.

Incubation experiments - Peat samples were incubated anaerobically at $10^{\circ} \mathrm{C}$ in $100-\mathrm{mL}$ infusion bottles as described before (Galand et al., 2002). For inhibition of acetoclastic methanogenesis methyl fluoride $\left(\mathrm{CH}_{3} \mathrm{~F}\right)(99 \%$, $\mathrm{ABCR}$, Karlsruhe, Germany) was added to the gas phase to give a final mixing ratio of $0.5-2.0 \% \mathrm{CH}_{3} \mathrm{~F}$. Aliquots of the gas phase were regularly analyzed for $\mathrm{CH}_{4}$ and $\mathrm{CO}_{2}$. Methane was analyzed by gas chromatography using a flame ionization detector; $\mathrm{CO}_{2}$ was analyzed after conversion to $\mathrm{CH}_{4}$ with a methanizer. At the end of incubation, the pore water was recovered by centrifugation and filtration through 0.2- $\mu \mathrm{m}$ pore size membrane filters (SRP 15; Sartorius, Göttingen, Germany). The $\mathrm{pH}$ was measured using a glass electrode. Acetate (and other fatty acids) was analyzed by high pressure liquid chromatography (HPLC) (Sykam, Gilching, Germany) equipped with both refraction index detector and UV detector (Krumböck \& Conrad 1991). The $\delta^{13} \mathrm{C}$ of $\mathrm{CH}_{4}$ and $\mathrm{CO}_{2}$ were analyzed by gas chromatography combustion isotope ratio mass spectrometry (GC-C-IRMS), and the $\delta^{13} \mathrm{C}$ of acetate was analyzed by HPLC-C-IRMS as described before (Conrad et al., 2007). Analysis of $\delta^{13} \mathrm{C}$ in organic matter was done at the Institute of Soil Science and Forest Nutrition (IBW) at the University of Göttingen using an elemental analyzer coupled to an IRMS. 
Calculations - Fractionation factors for a reaction A $\rightarrow$ B are defined after Hayes (Hayes 1993):

$\alpha_{\mathrm{A}, \mathrm{B}}=\left(\delta^{13} \mathrm{C}_{\mathrm{A}}+1000\right) /\left(\delta^{13} \mathrm{C}_{\mathrm{B}}+1000\right)$

sometimes expressed as isotopic enrichment factor $\varepsilon \equiv 1-$ $\alpha$ (in units of permil). The $\delta^{13} \mathrm{C}$ for a newly formed $\mathrm{CH}_{4}$ $\left(\delta^{13} \mathrm{C}_{\text {new }}\right)$ was calculated from the $\delta^{13} \mathrm{C}$ at two time points $\mathrm{t}$ $=1\left(\delta^{13} \mathrm{C}_{1}\right)$ and $\mathrm{t}=2\left(\delta^{13} \mathrm{C}_{2}\right)$ by the following mass balance Reaction:

$\delta^{13} \mathrm{C}_{2}=f_{\text {new }} \delta^{13} \mathrm{C}_{\text {new }}+\left(1-f_{\text {new }}\right) \delta^{13} \mathrm{C}_{1}$

with $f_{\text {new }}$ being the fraction of the newly formed Ccompound relative to the total at $\mathrm{t}=2$.

The fractionation factor for conversion of $\mathrm{H}_{2} / \mathrm{CO}_{2}$ to $\mathrm{CH}_{4}$ is given by

$\alpha_{\mathrm{CO}_{2}, \mathrm{CH}_{4}}=\left(\delta^{13} \mathrm{C}_{\mathrm{CO} 2}+1000\right) /\left(\delta^{13} \mathrm{C}_{\mathrm{CH}_{4}-\mathrm{CH}_{3} \mathrm{~F}}+1000\right)$

where $\delta^{13} \mathrm{C}_{\mathrm{CH}_{4}-\mathrm{CH}_{3} \mathrm{~F}}$ is the $\delta^{13} \mathrm{C}_{\mathrm{CH}_{4}}$ produced in the presence of $\mathrm{CH}_{3} \mathrm{~F}$, i.e., with acetoclastic methanogenesis inhibited.

Relative contribution of $\mathrm{H}_{2}+\mathrm{CO}_{2}$-derived $\mathrm{CH}_{4}$ to total $\mathrm{CH}_{4}$ was determined using the following mass balance Reaction (Conrad, 2005):

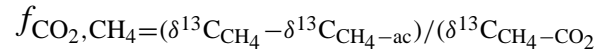

$\left.-\delta^{13} C_{\mathrm{CH}_{4}-\mathrm{ac}}\right)$

where $f_{\mathrm{CO}_{2}, \mathrm{CH}_{4}}$ is the fraction of $\mathrm{CH}_{4}$ formed from $\mathrm{H}_{2}$ $+\mathrm{CO}_{2}, \delta^{13} \mathrm{C}_{\mathrm{CH}_{4}}$ the $\delta^{13} \mathrm{C}$ of total produced methane, and

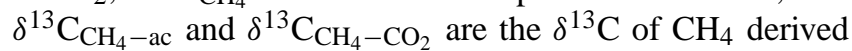
either from acetate or $\mathrm{H}_{2}+\mathrm{CO}_{2}$, which were determined by:

$\delta^{13} \mathrm{C}_{\mathrm{CH}_{4}-\mathrm{ac}}=\delta^{13} \mathrm{C}_{\text {org }}+\varepsilon_{\text {org }, \mathrm{CH}_{4}}$

$\delta^{13} \mathrm{C}_{\mathrm{CH}_{4}-\mathrm{CO}_{2}}=\delta^{13} \mathrm{C}_{\mathrm{CH}_{4}-\mathrm{CH}_{3} \mathrm{~F}}$

In general, calculations were done using the averaged data ( \pm standard error) from triplicate incubations. Total amounts of gases in the headspace of the incubation vessels were calculated from the partial pressures using the volume of the gas space and the gas constant.

\section{Results}

Production rates of $\mathrm{CH}_{4}$ were much higher in peat samples from the mesotrophic fen (MES) than from the ombrotrophic peat (OMB) and the oligotrophic fen (OLI) (Table 1). The same was found for $\mathrm{CO}_{2}$ production (Table 1). The extent of inhibition of $\mathrm{CH}_{4}$ production by $\mathrm{CH}_{3} \mathrm{~F}$ was larger in MES $>\mathrm{OMB}>\mathrm{OLI}$ (Table 1). Production of $\mathrm{CH}_{4}$ was progressively inhibited with increasing concentration of $\mathrm{CH}_{3} \mathrm{~F}$ reaching maximum inhibition at $2 \% \mathrm{CH}_{3} \mathrm{~F}$ (Fig. 1), except in OMB where it was already reached at $1 \% \mathrm{CH}_{3} \mathrm{~F}$
(Fig. 1). By contrast, maximum inhibition of $\mathrm{CO}_{2}$ production was already reached at $0.5 \% \mathrm{CH}_{3} \mathrm{~F}$. However, $\mathrm{CO}_{2}$ production was generally much less inhibited than $\mathrm{CH}_{4}$ production (Table 1). The concentration of acetate was also highest in MES (Table 1). Those in OLI and OMB were at least one order of magnitude lower. Inhibition of acetoclastic methanogenesis should result in accumulation of acetate. Indeed acetate accumulated in MES, on the average to about 3-fold higher concentrations. However, in OLI and OMB acetate accumulated only marginally (Table 1$)$. In MES, caproate $(<700 \mu \mathrm{M})$, propionate $(<500 \mu \mathrm{M})$, butyrate $(<200 \mu \mathrm{M})$, isopropanol $(<100 \mu \mathrm{M})$ and valerate $(<60 \mu \mathrm{M})$ also accumulated, but in OLI and OMB accumulation of these compounds was mostly not detectable.

The $\delta^{13} \mathrm{C}$ of the organic matter of the peat samples was similar in the different peat ecosystems, ranging between $-27.4 \%$ and $-26.5 \%$ o (Table 1). An effect of $\mathrm{CH}_{3} \mathrm{~F}$ on the ${ }^{13} \mathrm{C}$ of acetate could not be discerned. Therefore, all acetate data were averaged. The $\delta^{13} \mathrm{C}$ of the averaged acetate in OMB and OLI was only by $2 \%$ and $5 \%$ larger than that of $\mathrm{C}_{\text {org }}$. However, that of MES was by almost $9 \%$ larger than that of $\mathrm{C}_{\text {org }}$.

The $\delta^{13} \mathrm{C}$ of $\mathrm{CO}_{2}$ was relatively constant with incubation time (Fig. 1). It was similar for MES and OLI (i.e., about $-17 \%$ o) but was larger for OMB $(-11 \%$ ) (Table 1). Addition of $\mathrm{CH}_{3} \mathrm{~F}$ had only a slight effect on $\delta^{13} \mathrm{C}_{\mathrm{CO}_{2}}$, decreasing the values by a few permil only (Fig. 1). However, the $\delta^{13} \mathrm{C}$ of $\mathrm{CO}_{2}$ were generally much higher (on average $15 \%$ ) than those of $\mathrm{C}_{\mathrm{org}}$, (on average $-27 \%$ ), indicating that $\mathrm{CO}_{2}$ was fractionated during its further conversion to $\mathrm{CH}_{4}$. Such fractionation was apparent since the $\delta^{13} \mathrm{C}$ of $\mathrm{CH}_{4}$ was quite negative with values around $-58 \%$ in MES, $-66 \%$ in OMB and $-89 \%$ in OLI (Fig. 1, Table 1). Since $\mathrm{CH}_{4}$ can be produced from both hydrogenotrophic and acetoclastic pathways, the latter was inhibited by addition of $\mathrm{CH}_{3} \mathrm{~F}$ so that $\delta^{13} \mathrm{C}$ of $\mathrm{CH}_{4}$ was only affected by $\mathrm{CO}_{2}$ reduction. Under these conditions, $\delta^{13} \mathrm{C}_{\mathrm{CH}_{4}}$ indeed further decreased already at the lowest $\mathrm{CH}_{3} \mathrm{~F}$ concentration (Fig. 1). Interestingly, addition of $\mathrm{CH}_{3} \mathrm{~F}$ resulted only a comparatively small decrease of $\delta^{13} \mathrm{C}_{\mathrm{CH}_{4}}$ when added to OMB and OLI, indicating that acetoclastic methanogenesis did not contribute much to $\mathrm{CH}_{4}$ production in these peat ecosystems.

Assuming that any acetoclastic methanogenesis was inhibited completely by the presence of $\mathrm{CH}_{3} \mathrm{~F}$, it is possible to calculate the fractionation factor of hydrogenotrophic methano-

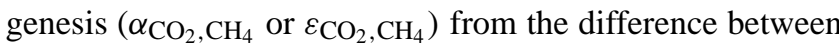
the $\delta^{13} \mathrm{C}_{\mathrm{CH}_{4}}$ in the absence and the presence of $\mathrm{CH}_{3} \mathrm{~F}$. The fractionation factor was largest in OLI $>$ MES $>$ OMB, i.e., $\varepsilon_{\mathrm{CO}_{2}, \mathrm{CH}_{4}}$ ranging between $-78.5 \%$ o and $-66.8 \%$ o (Table 1 ).

The fraction $\left(f_{\left.\mathrm{CO}_{2}, \mathrm{CH}_{4}\right)}\right)$ of hydrogenotrophically produced $\mathrm{CH}_{4}$ to total $\mathrm{CH}_{4}$ production was calculated from Eq. (4). The calculation assumed that the $\delta^{13} \mathrm{C}$ of hydrogenotroph-

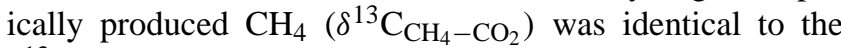
$\delta^{13} \mathrm{C}_{\mathrm{CH}_{4}}$ measured in the presence of $\mathrm{CH}_{3} \mathrm{~F}$, when acetoclastic methanogenesis was inhibited and $\mathrm{CH}_{4}$ was exclusively 

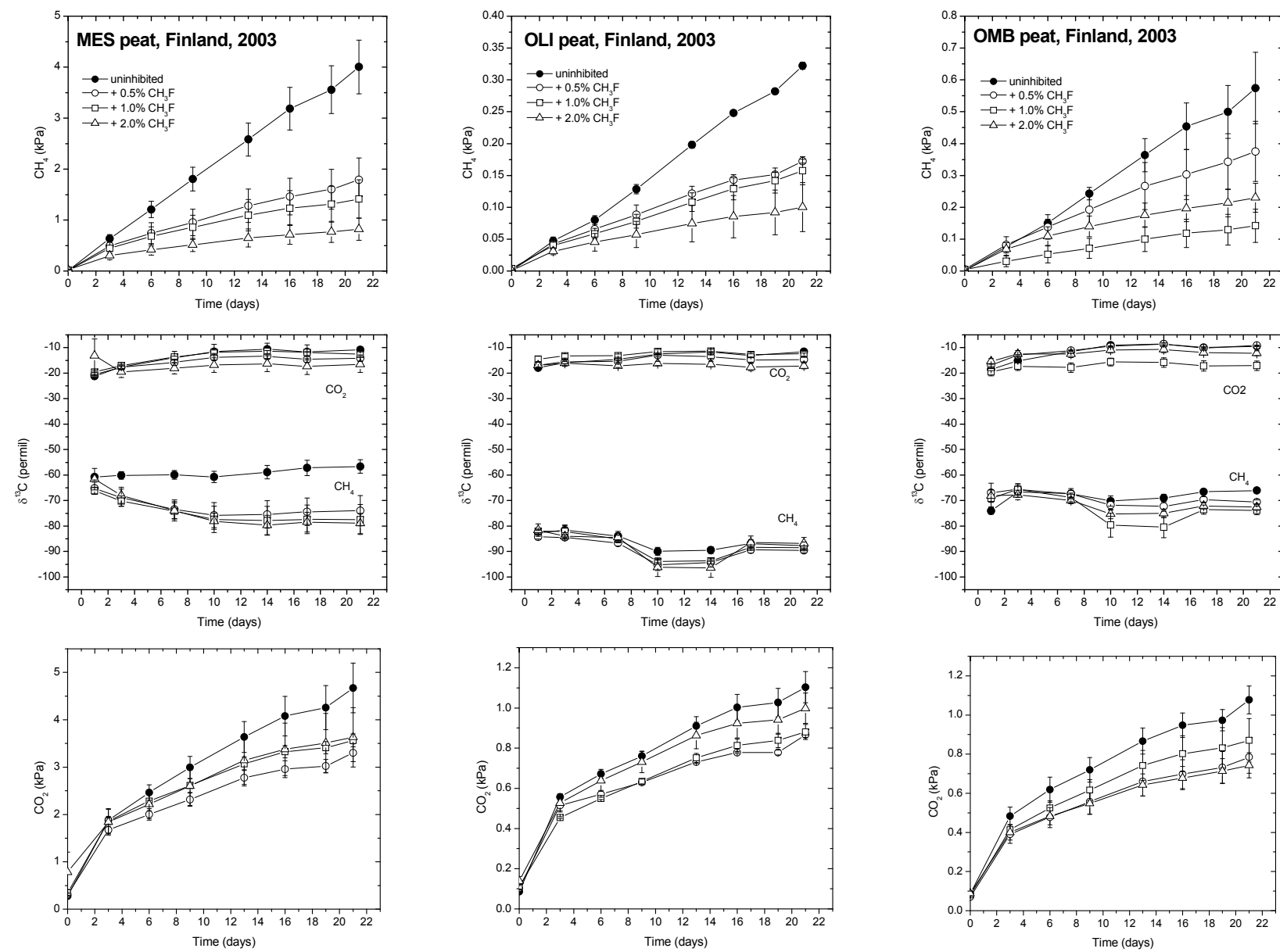

Fig. 1. Time course of accumulation of $\mathrm{CH}_{4}$ and $\mathrm{CO}_{2}$, and of $\delta^{13} \mathrm{C}$ of the accumulated $\mathrm{CH}_{4}$ and $\mathrm{CO}_{2}$ in the absence and presence of different concetrations of $\mathrm{CH}_{3} \mathrm{~F}$, an inhibitor of acetoclastic methanogenesis $\left(\mathrm{CH}_{3} \mathrm{~F}\right)$ using samples from three different peatland ecosystems in Finland, i.e., mesotrophic fen (MES), oligotrophic fen (OLI), and ombrotrophic bog (OMB); mean $\pm \mathrm{SE}, n=3$.

produced from $\mathrm{H}_{2} / \mathrm{CO}_{2}$. The calculation further assumed that the $\delta^{13} \mathrm{C}$ of acetoclastically produced $\mathrm{CH}_{4}\left(\delta^{13} \mathrm{C}_{\mathrm{CH}_{4}-\mathrm{ac}}\right)$ was similar to $\delta^{13} \mathrm{C}_{\text {org }}$. Previous studies have found that the $\delta^{13} \mathrm{C}$ of the acetate-methyl from which $\mathrm{CH}_{4}$ is formed is less than $9 \%$ o smaller than $\delta^{13} \mathrm{C}_{\text {org }}$ (Conrad et al., 2007, 2009a, 2009b, 2010b). In OMB and OLI acetate concentrations were so low that acetate was probably utilized as it was produced so that there was no further carbon isotope fractionation during the conversion of acetate-methyl to $\mathrm{CH}_{4}$. In MES, acetate concentrations were larger, so that further fractionation is feasible. This fractionation should be on the order of less than $10 \%$ as typical for Methanosaeta (Valentine et al., 2004; Penning et al., 2006), which was the prevailing acetoclastic methanogen in MES (Juottonen et al., 2005) (Galand et al., 2005). Therefore, we assumed values of $\delta^{13} \mathrm{C}_{\mathrm{CH}_{4}-\text { ac }}$ being 5-10\%o smaller than $\delta^{13} \mathrm{C}_{\text {org. }}$. The resulting $f_{\mathrm{CO}_{2}, \mathrm{CH}_{4}}$ showed that $\mathrm{CH}_{4}$ production in MES was predominantly by acetoclastic methanogenesis, whereas $\mathrm{CH}_{4}$ production in OMB and even more in OLI was predominately due to hydrogenotrophic methanogenesis (Table 1).

\section{Discussion}

Our study demonstrated that different peatlands in Finland exhibited different carbon isotope fractionation during degradation of organic matter under anaerobic conditions. These differences were obvious from the fact that while $\delta^{13} \mathrm{C}$ values of organic matter, the primary substrate, were similar $(-27$ to $-26 \%$ ) in all three peatlands, the $\delta^{13} \mathrm{C}$ values of $\mathrm{CH}_{4}$, the end product of degradation, were quite different. Rates of organic matter degradation, as shown by $\mathrm{CH}_{4}$ and $\mathrm{CO}_{2}$ production, and concentrations of the degradation intermediate acetate were also quite different among the three peatlands. The differences in stable carbon isotope fractionation were explained by different paths of organic matter degradation and different prevalence of the acetoclastic versus hydrogenotrophic methanogenesis. 
Table 1. Production rates of $\mathrm{CH}_{4}$ and $\mathrm{CO}_{2}$, concentrations of acetate, values of $\delta^{13} \mathrm{C}$, isotopic enrichment factors and fractions of $\mathrm{CH}_{4}$ produced from $\mathrm{CO}_{2}$ in samples from different boreal peatland ecosystems, i.e., mesotrophic fen (MES), oligotrophic fen (OLI), and ombrotrophic bog (OMB).

\begin{tabular}{lrrr}
\hline Variables & MES peat & OLI peat & OMB peat \\
\hline $\mathrm{pH}$ & $5.3 \pm 0.1$ & $5.2 \pm 0.1$ & $3.9 \pm 0.2$ \\
$\mathrm{CH}_{4}$ production $\left(\mathrm{nmol} \mathrm{h}^{-1} \mathrm{gdw}^{-1}\right)$ & $210 \pm 77$ & $15 \pm 4$ & $40 \pm 13$ \\
$\mathrm{CH}_{4}$ production $\left(\mathrm{nmol} \mathrm{h}^{-1} \mathrm{gdw}^{-1}\right),+2 \% \mathrm{CH}_{3} \mathrm{~F}$ & $38 \pm 7(18 \%)$ & $4.2 \pm 4.2(28 \%)$ & $14.6 \pm 3.3(36 \%)$ \\
$\mathrm{CO}_{2}$ production $\left(\mathrm{nmol} \mathrm{h}^{-1} \mathrm{gdw}^{-1}\right)$ & $167 \pm 99$ & $29 \pm 2$ & $45 \pm 6$ \\
$\mathrm{CO}_{2}$ production $\left(\mathrm{nmol} \mathrm{h}^{-1} \mathrm{gdw}^{-1}\right),+2 \% \mathrm{CH}_{3} \mathrm{~F}$ & $113 \pm 5(68 \%)$ & $25 \pm 1(86 \%)$ & $27 \pm 1(60 \%)$ \\
Acetate $(\mu \mathrm{M})$ & $800 \pm 490$ & $85 \pm 25$ & $30 \pm 20$ \\
Acetate $(\mu \mathrm{M}),+2 \% \mathrm{CH}_{3} \mathrm{~F}$ & $2420 \pm 1290$ & $125 \pm 125$ & $50 \pm 10$ \\
$\delta^{13} \mathrm{C}_{\mathrm{org}}(\%)$ & $-27.3 \pm 0.1$ & $-27.4 \pm 0.1$ & $-26.5 \pm 0.2$ \\
$\delta^{13} \mathrm{C}_{\mathrm{ac}}(\%), \pm 0.5-2 \% \mathrm{CH}_{3} \mathrm{~F}$ & $-18.8 \pm 1.3$ & $-22.3 \pm 0.6$ & $-24.3 \pm 1.4$ \\
$\delta^{13} \mathrm{C}_{\mathrm{CH}_{4}(\%)}(28.4 \pm 0.9$ & $-88.9 \pm 4.8$ & $-65.6 \pm 3.7$ \\
$\delta^{13} \mathrm{C}_{\mathrm{CH}_{4}}(\%),+2 \% \mathrm{CH}_{3} \mathrm{~F}$ & $-78.8 \pm 0.3$ & $-86.4 \pm 25.0$ & $-73.1 \pm 9.6$ \\
$\delta^{13} \mathrm{C}_{\mathrm{CO}_{2}(\%)}(\%)$ & $-16.8 \pm 0.2$ & $-16.9 \pm 0.3$ & $-11.5 \pm 0.4$ \\
$\varepsilon_{\mathrm{CO}_{2}, \mathrm{CH}_{4}}(\%)$ & $-72.6 \pm 7.3$ & $-78.5 \pm 29.3$ & $-66.8 \pm 11.2$ \\
$f_{\mathrm{CO}_{2}, \mathrm{CH}_{4}}(\%), \mathrm{A}^{1}$ & $46 \pm 2$ & $89 \pm 9$ & $78 \pm 4$ \\
$f_{\mathrm{CO}_{2}, \mathrm{CH}_{4}(\%), \mathrm{B}}^{1}$ & $41 \pm 2$ & $88 \pm 10$ & $76 \pm 4$ \\
\hline
\end{tabular}

${ }^{1} f_{\mathrm{CO}_{2}, \mathrm{CH}_{4}}$ was calculated using Eq. (4) assuming (A) $\delta^{13} \mathrm{C}_{\mathrm{CH}_{4}-\mathrm{ac}}=\delta^{13} \mathrm{C}_{\mathrm{org}}-5$, and (B) $\delta^{13} \mathrm{C}_{\mathrm{CH}_{4}-\mathrm{ac}}=\delta^{13} \mathrm{C}_{\mathrm{org}}-10$.

Production rates of $\mathrm{CH}_{4}$ and $\mathrm{CO}_{2}$ were highest in peat from a mesotrophic fen (MES). The rates in the other peat samples were less than $25 \%$ of those in MES. Rates were slightly higher in peat from the ombrotrophic bog (OMB) than the oligotrophic fen (OLI). Rates of $\mathrm{CH}_{4}$ production were higher than those previously reported by Juottonen et al. (2005), who sampled the peat in October whereas our samples were from August. Methanogenic degradation of organic matter normally expects the production of equimolar amounts of $\mathrm{CH}_{4}$ and $\mathrm{CO}_{2}$. In OLI and OMB, the rates of $\mathrm{CO}_{2}$ production were higher than those of $\mathrm{CH}_{4}$ production. The rates of $\mathrm{CO}_{2}$ production only consider the gaseous $\mathrm{CO}_{2}$ measured in the headspace of the incubation vessels. While bicarbonate concentrations were negligible in the acidic peat samples, the concentrations of dissolved $\mathrm{CO}_{2}$ as calculated from Henry's law (Stumm and Morgan, 1981) were not negligible. Thus, rates of total $\mathrm{CO}_{2}$ production (gaseous plus dissolved $\mathrm{CO}_{2}$ ) were about $50 \%$ higher than those of gaseous $\mathrm{CO}_{2}$ alone. Hence, only MES produced $\mathrm{CH}_{4}$ and $\mathrm{CO}_{2}$ in the expected equimolar amounts, while OMB and OLI produced much more $\mathrm{CO}_{2}$ than $\mathrm{CH}_{4}$. Such imbalance has frequently been observed in methanogenic peat samples, and has even been observed when great care was taken that potential inorganic oxidants such as oxygen, nitrate, sulphate, iron(III) etc. had been completely reduced (Yavitt and SeidmannZager, 2006). The reasons for such imbalance are unclear at the moment, but one possible answer is the use of organic oxidants for the degradation of organic matter, e.g. certain humic compounds that are reduced while others are concomitantly oxidized to $\mathrm{CO}_{2}$ (Heitmann et al., 2007; Keller et al., 2009). Based on our observations, we hypothesize that or- ganic oxidants are more important in the more oligotrophic than the mesotrophic peatlands.

The mesotrophic peat (MES) also exhibited much higher (more than 10 times) acetate concentrations at the end of incubation than the oligotrophic peat samples (OMB, OLI). These acetate concentrations were further increased when acetoclastic methanogenesis, the only conceivable acetate degradation process, was inhibited by $\mathrm{CH}_{3} \mathrm{~F}$. This stimulation was again more strongly expressed in MES than in OMB or OLI. Hence, MES behaved as expected for an environment in which organic matter is first fermented to acetate as the major fermentation product. Interestingly, MES also contained other potential fermentation products, i.e., caproate, propionate, butyrate, isopropanol, and valerate, albeit at much lower concentrations than acetate. Such compounds are frequently observed in methanogenic lake sediments or flooded soils (Lovley and Klug, 1982; Phelps and Zeikus 1985; Chin and Conrad, 1995), but were not detected in OMB and OLI. There, acetate and other fermentation products seemed to play a comparatively minor role in the degradation of organic matter.

If degradation produces only little acetate, then acetoclastic methanogenesis should be comparatively less important for $\mathrm{CH}_{4}$ production, which would predominantly be formed by $\mathrm{CO}_{2}$ reduction. Indeed, isotopic mass balance calculations indicate that $\mathrm{CH}_{4}$ production in OMB and OLI was mainly due to hydrogenotrophic methanogenesis accounting for more than $75 \%$ of total $\mathrm{CH}_{4}$ production. In MES, on the other hand, $\mathrm{CH}_{4}$ was mainly (about $54-59 \%$ ) produced by acetoclastic methanogenesis. These data are consistent with an earlier study in which the percentage contribution 
of hydrogenotrophic versus acetoclastic methanogenesis was determined by measuring the conversion of ${ }^{14} \mathrm{C}$-labelled bicarbonate to $\mathrm{CH}_{4}$ (Galand et al., 2005). Theoretically, one would expect that $>66 \%$ of the $\mathrm{CH}_{4}$ is produced by acetoclastic methanogenesis, if organic matter, such as polysaccharides, proteins, lipids etc., is completely degraded (Conrad 1999; Conrad et al., 2010a). Hence, it appears that even in MES part of the organic matter is degraded in a noncanonical way. We assume that in peatlands organic substances are only partially degraded rather than completely. This speculation is consistent with recent studies in lake sediments (Conrad et al., 2009a; 2010b), in particular with a study in the sediment of an acidic bog lake (Conrad et al., 2010a). Thus the complete degradation of an organic substance, e.g.,

$\mathrm{C}_{6} \mathrm{H}_{12} \mathrm{O}_{6}+2 \mathrm{H}_{2} \mathrm{O} \rightarrow 2 \mathrm{CH}_{3} \mathrm{COOH}+2 \mathrm{CO}_{2}+4 \mathrm{H}_{2}$

$2 \mathrm{CH}_{3} \mathrm{COOH} \rightarrow 2 \mathrm{CH}_{4}+2 \mathrm{CO}_{2}$

$4 \mathrm{H}_{2}+\mathrm{CO}_{2} \rightarrow \mathrm{CH}_{4}+2 \mathrm{H}_{2} \mathrm{O}$

net: $\mathrm{C}_{6} \mathrm{H}_{12} \mathrm{O}_{6} \rightarrow 3 \mathrm{CO}_{2}+3 \mathrm{CH}_{4}$

would contrast with incomplete degradation of an organic substance, e.g.,

$\mathrm{C}_{6} \mathrm{H}_{12} \mathrm{O}_{6}+2 \mathrm{H}_{2} \mathrm{O} \rightarrow \mathrm{C}_{4} \mathrm{H}_{8} \mathrm{O}_{4}+2 \mathrm{CO}_{2}+4 \mathrm{H}_{2}$

$4 \mathrm{H}_{2}+\mathrm{CO}_{2} \rightarrow \mathrm{CH}_{4}+2 \mathrm{H}_{2} \mathrm{O}$

net: $\mathrm{C}_{6} \mathrm{H}_{12} \mathrm{O}_{6} \rightarrow \mathrm{C}_{4} \mathrm{H}_{8} \mathrm{O}_{4}+\mathrm{CO}_{2}+\mathrm{CH}_{4}$

and the oxidation of one organic substance by using another one as oxidant, e.g.

$\mathrm{C}_{6} \mathrm{H}_{12} \mathrm{O}_{6}+\mathrm{C}_{4} \mathrm{H}_{8} \mathrm{O}_{4}+\mathrm{H}_{2} \mathrm{O} \rightarrow \mathrm{CO}_{2}+\mathrm{C}_{5} \mathrm{H}_{10} \mathrm{O}_{4}$

$+\mathrm{C}_{4} \mathrm{H}_{10} \mathrm{O}_{4}$

Our data concerning $f_{\mathrm{CO}_{2}, \mathrm{CH}_{4}}$ and relative production rates of $\mathrm{CH}_{4}$ versus $\mathrm{CO}_{2}$ would be consistent with organic matter in OMB and OLI being mainly degraded by processes Reactions (R6 and R7), while in MES being mainly degraded by process Reaction (R4).

This interpretation is also consistent with the effect of $\mathrm{CH}_{3} \mathrm{~F}$, which showed the strongest inhibition (18\% residual activity) for $\mathrm{CH}_{4}$ production in MES, which was presumably caused by complete inhibition of acetoclastic methanogenesis and in addition by partial inhibition of hydrogenotrophic methanogenesis. Although acetoclastic methanogenesis is more sensitive, hydrogenotrophic methanogenesis was found to be also inhibited at increasing concentrations of $\mathrm{CH}_{3} \mathrm{~F}$ (Conrad and Klose, 1999). Hence the observed decrease of $\mathrm{CH}_{4}$ production with increasing $\mathrm{CH}_{3} \mathrm{~F}$ (Fig. 1) is not unexpected. Acetoclastic methanogenesis was probably completely inhibited at $1 \% \mathrm{CH}_{3} \mathrm{~F}$, since values of $\delta^{13} \mathrm{C}_{\mathrm{CH}_{4}}$ did not decrease further when more $\mathrm{CH}_{3} \mathrm{~F}$ was added (Fig. 1). Only in MES, but not in OMB or OLI, did $\mathrm{CH}_{3} \mathrm{~F}$ result in a strong decrease of $\delta^{13} \mathrm{C}_{\mathrm{CH}_{4}}$. A strong decrease is expected when most of the $\mathrm{CH}_{4}$ is produced by acetoclastic methanogenesis, which exhibits a much lower fractionation factor $\left(\alpha_{a c, \mathrm{CH}_{4}} \approx\right.$ 1.009-1.025) (Valentine et al., 2004; Penning et al., 2006; Goevert and Conrad, 2009) than hydrogenotrophic methanogenesis (as much as $\alpha_{\mathrm{CO}_{2}, \mathrm{CH}_{4}} \approx 1.090$ ) (Conrad 2005; Penning et al., 2005). In OMB and even more so in OLI, $\delta^{13} \mathrm{C}_{\mathrm{CH}_{4}}$ exhibited very low values already when $\mathrm{CH}_{3} \mathrm{~F}$ was not applied and decreased only a bit further upon application. In MES, on the other hand, $\delta^{13} \mathrm{C}_{\mathrm{CH}_{4}}$ decreased only in the presence of $\mathrm{CH}_{3} \mathrm{~F}$ to values comparable to those found in OLI and OMB (note that data in Table 1 are from newly formed $\mathrm{CH}_{4}$ ). The isotopic fractionation factors determined were on the order of $\alpha_{\mathrm{CO}_{2}, \mathrm{CH}_{4}} \approx 1.067-1.078$, or $\varepsilon_{\mathrm{CO}_{2}, \mathrm{CH}_{4}} \approx-78$ to $-67 \%$; Table 1). Partial inhibition of hydrogenotrophic methanogenesis by $\mathrm{CH}_{3} \mathrm{~F}$ is also consistent with the observation that $\mathrm{CO}_{2}$ production was less inhibited by $\mathrm{CH}_{3} \mathrm{~F}$ than $\mathrm{CH}_{4}$ production. Inhibition of only acetoclastic methanogenesis would result in equal inhibition of $\mathrm{CO}_{2}$ and $\mathrm{CH}_{4}$ production because of Reaction (R2). Inhibition of process Reaction (R3), however, would inhibit $\mathrm{CO}_{2}$ consumption and thus result in more net $\mathrm{CO}_{2}$ production.

A previous study found that the MES, OLI and OMB peatlands can also be distinguished on the basis of their methanogenic archaeal communities (Galand et al., 2005). Interestingly, the most abundant group of methanogens in MES was related to putatively acetoclastic Methanosaeta spp. On the other hand, OMB had a completely different methanogenic community composition dominated by the Fen cluster of Methanomicrobiales, while OLI contained a more diverse community including different clades of the Fen Cluster and Rice Cluster I (now Methanocellales (Sakai et al., 2008)). These microbial community differences between peatlands probably explain the presence of different paths for organic matter degradation. Noteworthy, a second study, found similar proportions of putatively acetoclastic Methanosaeta spp. in both OLI and MES (Juottonen et al., 2005). That study was, however, done later during the year (October vs. August).

In summary, our experiments showed that methanogenesis in peatlands was driven by two fundamentally different processes. Canonical fermentation followed by acetoclastic and hydrogenotrophic methanogenesis was a major process only in the mesotrophic fen. In the oligotrophic peat, however, organic matter was apparently degraded to a large extent by a different path which finally involved hydrogenotrophic methanogenesis as the major process while acetate formation and acetoclastic methanogenesis played only a minor role. The exact path of methanogenesis in such oligotrophic peatlands is not completely clear, but probably involves incomplete degradation of organic substances and use of organic compounds as oxidants so that $\mathrm{CO}_{2}$ rather than $\mathrm{CH}_{4}$ is the major degradation product. Generally, however, $\mathrm{H}_{2} / \mathrm{CO}_{2}$ and acetate were both used for $\mathrm{CH}_{4}$ production thus contrasting 
the degradation process at sites where acetoclastic methanogenesis is completely lacking and acetate accumulates over the season (Dugglestone et al., 2002; Hines et al., 2008).

Acknowledgements. We thank Eeva-Stiina Tuittila and Jukka Laine (Forest Ecology, Helsinki, Finland) for their advice and support with sample taking and Melanie Klose (MPI Marburg) for giving technical instructions during the tracer and inhibition experiments. Pierre Galand's work was funded by the Academy of Finland and by a FEMS fellowship.

Edited by: U. Seibt

\section{References}

Avery, G. B., Shannon, R. D., White, J. R., Martens, C. S., and Alperin, M. J.: Effect of seasonal changes in the pathways of methanogenesis on the $\delta^{13} \mathrm{C}$ values of pore water methane in a Michigan peatland, Global Biogeochem. Cy., 13, 475-484, 1999.

Bartlett, K. B. and Harriss, R. C.: Review and assessment of methane emissions from wetlands, Chemosphere, 26, 261-320, 1993.

Chanton, J. P., Glaser, P. H., Chasar, L. S., Burdige, D. J., Hines, M. E., Siegel, D. I., Tremblay, L. B., and Cooper, W. T.: Radiocarbon evidence for theimportance of surface vegetation on fermentation and methanogenesis in contrasting types of boreal peatlands, Global Biogeochem. Cy., 22, GB4022, doi:10.1029/2008GB003274, 2008.

Chasar, L. S., Chanton, J. P., Glaser, P. H., Siegel, D. I., and Rivers, J. S.: Radiocarbon and stable carbon isotopic evidence for transport and transformation of dissolved organic carbon, dissolved inorganic carbon, and $\mathrm{CH}_{4}$ in a northern Minnesota peatland, Global Biogeochem. Cy., 14, 1095-1108, 2000.

Chin, K. J. and Conrad, R.: Intermediary metabolism in methanogenic paddy soil and the influence of temperature, FEMS Microbiol. Ecol., 18, 85-102, 1995.

Conrad, R.: Contribution of hydrogen to methane production and control of hydrogen concentrations in methanogenic soils and sediments [review], FEMS Microbiol. Ecol., 28, 193-202, 1999.

Conrad, R.: Quantification of methanogenic pathways using stable carbon isotopic signatures: a review and a proposal, Org. Geochem., 36, 739-752, 2005.

Conrad, R., Chan, O. C., Claus, P., and Casper, P.: Characterization of methanogenic Archaea and stable isotope fractionation during methane production in the profundal sediment of an oligotrophic lake (Lake Stechlin, Germany), Limnol. Oceanogr., 52, 1393 1406, 2007.

Conrad, R., Claus, P., and Casper, P.: Characterization of stable isotope fractionation during methane production in the sediment of a eutrophic lake, Lake Dagow, Germany, Limnol. Oceanogr., 54, 457-471, 2009a.

Conrad, R., Claus, P., and Casper, P.: Stable isotope fractionation during the methanogenic degradation of organic matter in the sediment of an acidic bog lake, Lake Grosse Fuchskuhle, Limnol.Oceanogr., 54, 1932-1942, 2010a.

Conrad, R. and Klose, M.: How specific is the inhibition by methyl fluoride of acetoclastic methanogenesis in anoxic rice field soil? FEMS Microbiol. Ecol., 30, 47-56, 1999.
Conrad, R., Klose, M., Claus, P., and Dan, J.: Activity and composition of the methanogenic archaeal community in soil vegetated with wild rice versus cultivated rice, Soil Biol. Biochem., 41, 1390-1395, 2009b.

Conrad, R., Klose, M., Claus, P., and Enrich-Prast, A.: Methanogenic pathway, ${ }^{13} \mathrm{C}$ isotope fractionation, and archaeal community composition in the sediment of two clearwater lakes of Amazonia, Limnol. Oceanogr., 55, 689-702, 2010 b.

Duddleston, K. N., Kinney, M. A., Kiene, R. P., and Hines, M. E.: Anaerobic microbial biogeochemistry in a northern bog: Acetate as a dominant metabolic end product, Global Biogeochem. Cy., 16, 1063, doi:10.1029/2001GB001402, 2002.

Galand, P. E., Fritze, H., Conrad, R., and Yrjälä, K.: Pathways for methanogenesis and diversity of methanogenic archaea in three boreal peatland ecosystems, Appl. Environ. Microbiol., 71, 2195-2198, 2005.

Galand, P. E., Saarnio, S., Fritze, H., and Yrjälä, K.: Depth related diversity of methanogen Archaea in Finnish oligotrophic fen, FEMS Microbiol. Ecol. 42, 441-449, 2002.

Goevert, D. and Conrad, R.: Effect of substrate concentration on carbon isotope fractionation during acetoclastic methanogenesis by Methanosarcina barkeri and M. acetivorans and in rice field soil, Appl. Environ. Microbiol., 75, 2605-2612, 2009.

Gorham, E.: Northern peatlands - Role in the carbon cycle and probable responses to climatic warming, Ecol. Appl., 1, 182195, 1991.

Hayes, J. M.: Factors controlling ${ }^{13} \mathrm{C}$ contents of sedimentary organic compounds: principles and evidence, Mar. Geol., 113, 111-125, 1993.

Heitmann, T., Goldhammer, T., Beer, J., and Blodau, C.: Electron transfer of dissolved organic matter and its potential significance for anaerobic respiration in a northern bog, Glob. Change Biol., 13, 1771-1785, 2007.

Hines, M. E., Duddleston, K. N., Rooney-Varga, J. N., Fields, D., and Chanton, J. P.: Uncoupling of acetate degradation from methane formation in Alaskan wetlands: Connections to vegetation distribution, Global Biogeochem. Cy., 22, GB2017, doi:10.1029/2006GB002903, 2008.

Horn, M. A., Matthies, C., Küsel, K., Schramm, A., and Drake, H. L.: Hydrogenotrophic methanogenesis by moderately acidtolerant methanogens of a methane-emitting acidic peat, Appl. Environ. Microbiol., 69, 74-83, 2003.

Hornibrook, E. R. C., Longstaffe, F. J., and Fyfe, W. S.: Evolution of stable carbon isotope compositions for methane and carbon dioxide in freshwater wetlands and other anaerobic environments, Geochim. Cosmochim. Ac., 64, 1013-1027, 2000.

Juottonen, H., Galand, P. E., Tuittila, E. S., Laine, J., Fritze, H., and Yrjälä, K.: Methanogen communities and Bacteria along an ecohydrological gradient in a northern raised bog comple, Environ. Microbiol., 7, 1547-1557, 2005.

Keller, J. K., Weisenhorn, P. B., and Megonigal, J. P.: Humic acids as electron acceptors in wetland decomposition, Soil Biol. Biochem., 41, 1518-1522, 2009.

Knorr, K.-H., Glaser, B., and Blodau, C.: Fluxes and ${ }^{13} \mathrm{C}$ isotopic composition of dissolved carbon and pathways of methanogenesis in a fen soil exposed to experimental drought, Biogeosciences, 5, 1457-1473, doi:10.5194/bg-5-1457-2008, 2008.

Kotsyurbenko, O. R., Chin, K. J., Glagolev, M. V., Stubner, S., Simankova, M. V., Nozhevnikova, A. N., and Conrad, 
R.: Acetoclastic and hydrogenotrophic methane production and methanogenic populations in an acidic West-Siberian peat bog, Environ. Microbiol., 6, 1159-1173, 2004.

Kotsyurbenko, O. R., Friedrich, M. W., Simankova, M. V., Nozhevnikova, A. N., Golyshin, P. N., Timmis, K. N., and Conrad, R.: Shift from acetoclastic to $\mathrm{H}_{2}$-dependent methanogenesis in a West Siberian peat bog at low $\mathrm{pH}$ values and isolation of an acidophilic Methanobacterium strain, Appl. Environ. Microbiol., 73, 2344-2348, 2007.

Krumböck, M. and Conrad, R.: Metabolism of position-labelled glucose in anoxic methanogenic paddy soil and lake sediment, FEMS Microbiol. Ecol., 85, 247-256, 1991.

Lansdown, J. M., Quay, P. D., and King, S. L.: $\mathrm{CH}_{4}$ production via $\mathrm{CO}_{2}$ reduction in a temperate bog: a source of ${ }^{13} \mathrm{C}$-depleted $\mathrm{CH}_{4}$, Geochim. Cosmochim. Ac., 56, 3493-3503, 1992.

Lovley, D. R. and Klug, M. J.: Intermediary metabolism of organic matter in the sediments of a eutrophic lake, Appl. Environ. Microbiol., 43, 552-560, 1982.

Matthews, E. and Fung, I.: Methane emission from natural wetlands: Global distribution, area, and environmental characteristics of sources, Global Biogeochem. Cy., 1, 61-86, 1987.

Metje, M. and Frenzel, P.: Effect of temperature on anaerobic ethanol oxidation and methanogenesis in acidic peat from a northern wetland, Appl. Environ. Microbiol., 71, 8191-8200, 2005.

Metje, M. and Frenzel, P.: Methanogenesis and methanogenic pathways in a peat from subarctic permafrost, Environ. Microbiol., 9, 954-964, 2007.

Nakagawa, F., Yoshida, N., Nojiri, Y., and Makarov, V. N.: Production of methane from alasses in eastern Siberia: Implications from its ${ }^{14} \mathrm{C}$ and stable isotopic compositions, Global Biogeochem. Cy., 16, 3, doi:10.1029/2000GB001384, 2002.

Penning, H., Claus, P., Casper, P., and Conrad, R.: Carbon isotope fractionation during acetoclastic methanogenesis by Methanosaeta concilii in culture and a lake sediment, Appl. Environ. Microbiol., 72, 5648-5652, 2006.

Penning, H., Plugge, C. M., Galand, P. E., and Conrad, R.: Variation of carbon isotope fractionation in hydrogenotrophic methanogenic microbial cultures and environmental samples at different energy status, Global Change Biol., 11, 2103-2113, 2005 .
Phelps, T. J. and Zeikus, J. G.: Effect of fall turnover on terminal carbon metabolism in Lake Mendota sediments, Appl. Environ. Microbiol., 50, 1285-1291, 1985.

Popp, T. J., Chanton, J. P., Whiting, G. J., and Grant, N.: Methane stable isotope distribution at a Carex dominated fen in north central Alberta, Global Biogeochem. Cy., 13, 1063-1077, 1999.

Prater, J. L., Chanton, J. P., and Whiting, G. J.: Variation in methane production pathways associated with permafrost decomposition in collapse scar bogs of Alberta, Canada, Global Biogeochem. Cy., 21, GB4004, doi:10.1029/2006GB002866, 2007.

Rooney-Varga, J. N., Giewat, M. W., Duddleston, K. N., Chanton, J. P., and Hines, M. E.: Links between archaeal community structure, vegetation type and methanogenic pathway in Alaskan peatlands, FEMS Microbiol. Ecol., 60, 240-251, 2007.

Sakai, S., Imachi, H., Hanada, S., Ohashi, A., Harada, H., and Kamagata, Y.: Methanocella paludicola gen. nov., sp. nov., a methane-producing archaeon, the first isolate of the lineage 'Rice Cluster I', and proposal of the new archaeal order Methanocellales ord. nov., Int. J. Syst. Evol. Microbiol., 58, 929-936, 2008.

Steinmann, P., Eilrich, B., Leuenberger, M., and Burns, S. J.: Stable carbon isotope composition and concentrations of $\mathrm{CO}_{2}$ and $\mathrm{CH}_{4}$ in the deep catotelm of a peat bog, Geochim. Cosmochim. Ac., 72, 6015-6026, 2008.

Stumm, W. and Morgan, J. J.: Aquatic Chemistry. An Introduction Emphasizing Chemical Equilibria in Natural Waters, Wiley, New York, 1981.

Valentine, D. L., Chidthaisong, A., Rice, A., Reeburgh, W. S., and Tyler, S. C.: Carbon and hydrogen isotope fractionation by moderately thermophilic methanogens, Geochim. Cosmochim. Ac., 68, 1571-1590, 2004.

Whiticar, M. J., Faber, E., and Schoell, M.: Biogenic methane formation in marine and freshwater environments: $\mathrm{CO}_{2}$ reduction vs. acetate fermentation - isotopic evidence, Geochim. Cosmochim. Ac., 50, 693-709, 1986.

Yavitt, J. B. and Seidmann-Zager, M: Methanogenic conditions in northern peat soils, Geomicrobiol. J., 23, 119-127, 2006.

Zinder, S. H.: Physiological ecology of methanogens, edited by: Ferry, J. G., Methanogenesis, Ecology, Physiology, Biochemistry and Genetics (128-206), Chapman \& Hall, New York, 1993. 